\title{
Peran Guru Pendidikan Agama Islam dalam Menanggulangi Kenakalan Peserta Didik
}

\author{
Ana Maulida1, Rini Rahman ${ }^{2}$ \\ maulidaana534@gmail.com ${ }^{1}$, rinirahman@fis.unp.ac.id ${ }^{2}$ \\ Universitas Negeri Padang1,2
}

\begin{tabular}{|c|c|}
\hline ART & \multirow{13}{*}{$\begin{array}{l}\text { ABSTRACT } \\
\text { This study was conducted to determine the reality of } \\
\text { student delinquency, to determine the factors causing student } \\
\text { delinquency, and to describe the efforts of Islamic Religious } \\
\text { Education teachers in tackling student delinquency. The } \\
\text { method used in this study is a qualitative method with a } \\
\text { phenomenological approach. Data was sourced from } \\
\text { interviews with the Principal, Deputy Principal for Student } \\
\text { Affairs, PAI teachers, and Counseling Guidance teachers. The } \\
\text { results showed that the reality of delinquency in SMP Negeri } 6 \\
\text { Bukittingi students was divided into } 3 \text { levels, the first being } \\
\text { mild delinquency, for example coming late to school, dressing } \\
\text { untidily, leaving class during PBM, and not doing assignments. } \\
\text { Second, delinquency that disturbs the peace and security of } \\
\text { others and sexual delinquency, for example, speeding on the } \\
\text { street, fighting, noisy during PBM, and smoking. Third, sexual } \\
\text { delinquency, for example, dating and socializing knows no } \\
\text { boundaries. The causes of student delinquency there are three } \\
\text { factors, namely: family environment, school, and community. } \\
\text { The efforts of Islamic Religious Education teachers in tackling } \\
\text { student delinquency are preventive, repressive, and curative } \\
\text { actions. }\end{array}$} \\
\hline Artic & \\
\hline Received, 21 Oktober 2021 & \\
\hline Revised, 25 Desem & \\
\hline Accepted, 28 Februari 2022 & \\
\hline Kevwerds. & \\
\hline кеуи & \\
\hline PAI, & \\
\hline Menanggulangi, Kenakalan & \\
\hline Peserta Didik & \\
\hline $\begin{array}{l}\text { Conflict of Interest: } \\
\text { None }\end{array}$ & \\
\hline Funding: & \\
\hline Nc & \\
\hline
\end{tabular}

Corresponding Author: Ana Maulida, Department Islamic Education Faculty of Social Science Universitas Negeri Padang, Indonesia, Email: maulidaana534@gmail.com, Phone No.: $+6282171342649$

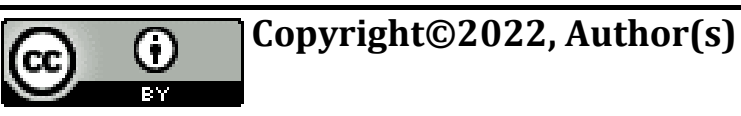

\section{Pendahuluan}

Masa remaja atau adolescence berasal dari bahasa latin adolescere yang berarti "tumbuh" menjadi dewasa". Apabila diartikan dalam konteks yang lebih luas, akan mencakup kematangan mental, emosional, sosial dan fisik (Piaget dalam Jannah, 244). Masa remaja merupakan masa yang penuh dengan rintangan, masa perubahan dari kanak-kanak yang masih bergantung kepada orang tua menuju dewasa yang sudah matang dan mampu berdiri sendiri. Dalam penjelasan yang lain masa remaja lah masa bergejolaknya berbagai macam perasaan yang kadang-kadang satu sama lain sering bertentangan dan sehingga remaja terombang ambing di antara berbagai macam perasaan yang bertentangan. Di antara sebab-sebab kegoncangan perasaan adalah 
Ana Maulida dan Rini Rahman: Peran Guru Pendidikan Agama Islam dalam....

pertentangan ketidakserasian yang terdapat dalam lingkungan keluarga, lingkungan sekolah dan lingkungan masyarakat.

Dalam proses mencari jati dirinya, seringkali para remaja menunjukkan perilaku yang bertentangan dengan nilai, norma agama dan masyarakat. Tingkah laku yang ditunjukkan oleh remaja tersebut merupakan reaksi dari dalam dirinya untuk mendapatkan suatu perhatian dari orang lain. Kondisi seperti ini sering tidak mendapat respon dari orang tua maupun orang dewasa lainnya sehingga hal tersebut berpengaruh terhadap perkembangan jiwa remaja yang sedang mengalami gejolak. Kehidupan kejiwaannya ditandai dengan tidak adanya kegoncangan atau kecemasan yang menyertai rasa bersalah, rasa cemas, rasa tidak puas, rasa kurang dan keluhan terhadap nasib yang dialaminya (Chouirudin, 2015:3).

Masa remaja dikatakan sebagai masa yang mempunyai emosi yang tidak stabil, sehingga merangsang adanya perilaku negatif ataupun yang biasa disebut dengan kenakalan remaja. Menurut Prasanti (2017), kenakalan remaja merupakan perbuatan/ kejahatan/ pelanggaran yang dilakukan oleh remaja yang bersifat melawan hukum, anti susila, dan menyalahi norma-norma agama.

Kenakalan remaja mempunyai 4 aspek, antara lain: 1) perilaku yang membahayakan orang lain serta diri sendiri, semacam kebut-kebutan dijalan, menerobos lalu lintas, merokok, narkoba dan lain-lain. 2) Perilaku yang melanggar hukum seperti melanggar lalu lintas, mencuri, merambok serta banyak lagi perilaku-perilaku yang melanggar hukum. 3) perilaku yang menimbulkan korban fisik, seperti tawuran antar sekolah ataupun berkelahi dengan teman satu sekolah dan lain sebagainya. 4) Perilaku yang memunculkan korban materi seperti mencuri, memalak, merusak sekolah ataupun sarana umum lainnya (Sarwono, 2002).

Kenakalan remaja bukan hanya sebatas perbuatan usil dan jahil yang dilakukan dengan tanpa sengaja tetapi dapatjuga meliputi kenakalan atau perbuatan remaja yang berlawanan dengan KUHP ataupun dalam perundang-undangan di luar KUHP (pidana khusus). Dapat pula terjadi perbuatan anak remaja yang bersifat anti sosial dan memunculkan keresahan pada masyarakat, sekolah, dan keluarga. Contoh sederhana dalam hal ini berupa coret-coret tidak pada tempatnya misalnya pada tembok pagar, mengganggu orang di jalan, pencurian oleh anak remaja, mengedarkan pornografi, menghisap ganja, dan perkelahian dikalangan peserta didik yang sering kali berkembang menjadi perkelahian antar sekolah. (Sinaga: 2020).

Guru PAI harus memiliki strategi dalam proses mengajar untuk memberikan pengetahuan kepada siswa. Mengajarkan dan menanamkan nilai-nilai karakter agar siswa dapat memiliki karakter dan perilaku yang diharapkan. Strategi yang matang sangat diperlukan agar tujuan tujuan yang akan dicapai bisa berjalan dengan baik. Strategi guru harus dapat memperbaiki dan membentuk akhlak siswa sampai akhir hayatnya. Oleh karena itu semua unsur yang membentuk sebuah strategi harus terpenuhi. Jika tidak ada sebuah strategi yang dapat berdiri sendiri dalam pembelajaran mata pelajaran ini, maka dapat dikombinasikan dengan strategi-strategi lain yang sesuai sehingga karakter bangsa seperti yang diamanatkan oleh agama dan proklamasi kemerdekaan bangsa Indonesia tercapai secara sepurna (Darmiah, 2017).

Selain guru sekolah pun juga harus berperan dalam mewujudkan karakter yang baik. Sekolah harus membuat cara agar sekolah tersebut menjadi komunitas kebajikan, suatu tempat di mana kualitas moral dan intelektual seperti penilaian yang baik, usaha yang terbaik, sikap hormat, kebaikan, kejujuran, pelayanan, dan kewarganegaraan 
dijadikan model, ditegakkan, dipraktekan dalam setiap bagian kehidupan sekolah. Semua yang diberikan di sekolah merupakan kelanjutan dari apa yang diberikan di dalam keluarga, akan tetapi tingkatannya jauh lebih tinggi dan lebih kompleks sesuai jenjangnya. Pengetahuan tersebut bersumber dari disiplin-disiplin ilmu dan permasalahan-permasalahan yang berkembang dalam masyarakat (Thomas: 2012)

SMPN 6 Bukittinggi merupakan salah satu lembaga pendidikan formal negeri yang berbasis umum dan memiliki seperangkat peraturan atau tata tertib sekolah yang bersifat mengikat bagi seluruh siswa. Peraturan ini bertujuan untuk menciptakan suasana kondusif bagi berlangsungnya kegiatan belajar mengajar serta membentuk siswa agar mempunyai kepribadian yang baik dan disiplin dalam aspek kehidupan.

Berdasarkan observasi dan wawancara yang dilakukan pada tanggal 17 Juli 2021 dengan Ibu Syamsimar, S.Pd selaku Kepala Sekolah SMPN 6 Bukittinggi beliau mengatakan bahwa upaya guru PAI dalam menanggulangi kenakalan siswa yaitu dengan mengadakan kegiatan tadarus Al-Quran, pesantren kilat, peringatan hari besar Islam, dan sholat berjamaah. Menurut beliau bahwa hal yang melatarbelakangi sekolah menerapkan kegiatan tadarus Al-Quran, pesantren kilat, dan peringatan hari besar islam sebagaimana disampaikan oleh bapak Kepala Sekolah yaitu banyak peserta didik yang kurang tepat waktu dalam berangkat sekolah, gaduh dalam kelas, mencontek, membolos, merokok, dan berkelahi sehingga hal ini yang membuat guru PAI harus berupaya semaksimal mungkin dalam menanggulangi kenakalan, khususnya kenakalan yang menyangkut norma agama dan tingkah laku keberagamaan. Berdasarkan latar belakang diatas penulis menganggap penelitian tentang upaya guru PAI dalam menanggulangi kenakan siswa sangat penting dilakukan, karena guru PAI mempunyai peran penting dalam pembentukan kepribadian siswa yang baik di SMPN 6 Bukittinggi.

\section{Tinjauan Pustaka}

Istilah kenakalan berasal dari kata dasar "Nakal" (bahasa jawa), yang secara harfiah muncul dari kata "Ana Akal" yang artinya "ada akal atau timbulnya akalnya" yang artinya suka berbuat kurang baik, suka mengganggu dan sebagainya terutama pada anak-anak. Dengan demikian dapat dikatakan bahwa kenakalan berarti perbuatan yang dilakukan anak-anak pada umumnya melanggar norma sosial, norma agama, norma hukum, norma kelompok, dan mengganggu ketentraman masyarakat, atau perbuatan yang tidak pantas dilakukan baik itu dilingkungan sekolah maupun di luar sekolah. (Hisyam, 2020).

Kenakalan berasal dari kata "nakal" yang berarti kurang baik (tidak menurut, mengganggu dan sebagainya) terutama pada anak-anak. Istilah kenakalan berarti tingkah laku secara ringan yang menyalahi norma dan hukum yang berlaku di masyarakat. Berkaitan dengan siswa berarti perilaku siswa yang menyalahi norma dan hukum yang berlaku dalam suatu lingkungan masyarakat sekolah. Maka dapat disimpulkan bahwa kenakalan merupakan perilaku yang berupa penyimpangan atau pelanggaran pada norma yang berlaku. Depdiknas (2002).

Ditinjau dari segi agama kenakalan ini erat kaitannya dengan akhlak, Islam telah menetapkan tata cara kehidupan umatnya, maka tidak mengherankan jika Nabi Muhammad sendiri pun menyatakan tujuan kerasulannya adalah untuk menyempurnakan akhlak. Akhlak mempunyai kedudukan yang tinggi dan istimewa dalam Islam. Rasulullah SAW menempatkan penyempurnaan akhlak yang mulia 
Ana Maulida dan Rini Rahman: Peran Guru Pendidikan Agama Islam dalam....

sebagai misi pokok risalah Islam. Kata akhlak (bahasa Arab), secara etimologis adalah bentuk jamak dari kata khuluq. Khuluq di dalam Kamus al-Munjid berarti budi. Berdasarkan pengertian etimologis tersebut, 5 akhlak tidak hanya merupakan tata aturan atau norma perilaku yang mengatur hubungan antara sesama manusia, tetapi juga norma yang mengatur hubungan antara sesama manusia dengan Tuhan dan bahkan dengan alam semestapekerti, perangai, tingkah laku, dan tabiat. Akhlak berakar dari kata kha-la-qa yang berarti menciptakan.

Sepanjang sejarah umat manusia, masalah akhlak juga selalu menjadi pokok persoalan, karena perilaku manusia secara langsung ataupun tidak langsung masih menjadi tolak ukur untuk mengetahui dan menilai perbuatan atau sikap mereka. Akhlak dalam kehidupan manusia menduduki tempat penting sekali dalam baik sebagai anggota masyarakat dan bangsa, sebab jatuh bangun, jaya hancurnya, sejahtera rusaknya suatu bangsa dan masyarakat dan tergantung pada akhlaknya. Apabila akhlaknya baik, maka baik pula lahir batinnya dan sebaliknya jika jelek akhlaknya, jelek pula lahir batinyya. Akhlak merupakan bagian penting yang tidak dapat dipisahkan dalam kehidupan manusia, tanpa akhlak, manusia akan hilang derajat kemanusiaannya sebagai makhluk yang mulia. (Setiawan, 2017).

Masalah kenakalan remaja mulai mendapat perhatian masyarakat secara khusus sejak terbentuknya peradilan untuk anak-anak nakal (juvenile court) pada 1899 di Illinois, Amerika Serikat. Kenakalan remaja meliputi semua perilaku yang menyimpang dari normanorma hukum pidana yang dilakukan oleh remaja. Perilaku tersebut akan merugikan dirinya sendiri dan orang-orang di sekitarnya (Sumara, dkk., 2017:352). Masalah kenakalan remaja merupakan masalah yang menjadi perhatian orang dimana saja, masalah ini semakin dirasakan masyarakat terutama di lingkungan sekolah. Bentuk-bentuk kenakalan remaja menurut Zakiah Daradjat dalam bukunya yang berjudul Membina Nilai-Nilai Moral dibagi menjadi 3 bagian, diantara: a) kenakalan ringan, b) kenakalan yang mengganggu ketenteraman dan keamanan orang lain, c) kenakalan seksual.

Sedangkan menurut Islam bentuk-bentuk kenakalan remaja adalah segala perbuatan tercela yang pada dasarnya di benci oleh Allah. Akhlak tercela yaitu akhlak yang tercermin dalam diri seseorang yang selalu bermuka masam, tidak sopan, sombong, pendusta, penakut, dan berbagai sifat yang tidak baik. Orang yang buruk akhlaknya menjadikan orang lain benci kepadanya, menjadi celaan dan tersisih dari pergaulan dan menyusahkan orang lain. Dalam bermasyarakat ia selalu resah, tidak mempunyai teman, dan tidak disukai masyarakat disekitarnya. Adapun pangkal dari segala akhlak tercela adalah kesombongan, penghinaan dan peremehan. (Yuanita, 2019).

Sudarsono (2012) dalam bukunya menjelaskan bahwa ada 3 faktor yang mendorong peserta didik untuk melakukan kenakalan, yaitu: a) keadaan keluarga, b) keadanaan teman, c) keadaan masyarakat. Dari pernyataan di atas maka dapat dimengerti bahwa penyebab munculnya kenakalan bersumber dari berbagai macam faktor yang berhubungan dengan siswa. Faktor tersebut bisa berasal dari dalam maupun dari luar diri siswa tersebut.

\section{Metode}

Penelitian ini menggunakan metode kualitatif dengan pendekatan fenomenologi. Menurut Mulyana (dalam Prasanti, 2018:16) metodologi adalah proses, prinsip, dan 
prosedur yang kita gunakan untuk mendekati problem dan mencari jawaban. Menurut Sugiyono (dalam Pratiwi, 2017:210), metode penelitian kualitatif adalah metode penelitian yang berlandaskan pada filsafat postpostivisme, digunakan untuk meneliti pada kondisi objek yang alamiah, (sebagai lawannya adalah eksperimen) dimana peneliti adalah sebagai instrumen kunci, teknik pengumpulan data yaitu purposive sampling. Menurut Melati (dalam Yetti, dkk., 2016:127), metode purposive sampling merupakan metode penelitian dengan pengambilan sampel secara sengaja sesuai dengan persyaratan yang diperlukan.

Sumber data penelitian ini diambil kepada beberapa informan melalui wawancara langsung yang terdiri dari Kepala Sekolah, Wakil Kepala Sekolah bidang Kesiswaan, Guru Pendidikan Agama Islam, dan Guru Bimbingan Konseling. Untuk memperkuat data penelitian penulis juga mengambil data melalui observasi kepada pendidik yang memberikan pembeajaran tentang agama kepada peserta didik. Selanjutnya sebagai bukti penulis menjalankan penelitian terkait isu dan permasalah yang dikaji, maka penulis juga mengabadikan seluruh kegiatan yang dilakukan seperti wawancara langsung dengan informan aktifitas belajar peserta didik, dan upaya dalam menanggulangi kenakalan siswa. Data wawancara penulis dengan informan dianalisis secara kolektif. Bogdan dan Bilen dalam Moleong (2014: 106) mengungkapkan analisis data adalah upaya yang dilakukan dengan jalan bekerja dengan data, mengorganisasikan data, memilah-milahnya menjadi satuan yang dapat dikelola, mesintesiskannya, mencari menemukan pola, menemukan apa yang penting dan apa yang dipelajari, dan memutuskan apa yang dapat diceritakan kepada orang lain. Proses analisis data yang diperoleh dari SMP Negeri 6 Bukittingi dimulai dengan menelaah seluruh data yang tersedia dari berbagai sumber, yaitu dari observasi, wawancara dan dokumen-dokumen yang berhubungan dengan penelitian seperti dokumen pribadi, dokumen resmi, gambar, foto dan sebagainya. Cara yang digunakan peneliti dalam menguji keabsahan data yaitu menggunakan triangulasi. Triangulasi merupakan suatu cara mengkaji keabsahan data dengan memanfaatkan berbagai sumber, berbagai waktu dari data yang telah dikumpulkan (Sugiyono, 2007).

\section{Hasil dan Pembahasan}

\section{Bentuk-Bentuk Kenakalan Siswa SMPN 6 Bukittinggi}

Untuk mendukung bukti data yang peneliti perolah dari wawancara sebagaimana diatas, berikut peneliti sertakan hasil wawancara dengan Kepala Sekolah, Guru Pendidikan Agama Islam, Wakil Kesiswaan dan Guru BK sebagai data pelengkap yang fungsinya memperkuat data-data yang peneliti peroleh dari hasil observasi, wawancara dan dokumentasi.

Seperti yang diungkapkan oleh Guru PAI yaitu bapak Mauli Wardi, S. PdI. wawancara 24 Agustus 2021, mengungkapkan bahwa: "Kenakalan yang sering dilakukan oleh siswa-siswa SMPN 6 Bukittinggi biasanya yaitu berkelahi, merokok, pertemanan antara laki-laki dan perempuan yang lewat batas, berkata-kata kasar, dan berpakaian tidak rapi". Hal yang sama diungkapkan oleh Wakil Kesiswaan yaitu bapak Firman Adhani, S. Pd wawancara 31 Agustus 2021 "Selama ini yang sering dilakukan 
Ana Maulida dan Rini Rahman: Peran Guru Pendidikan Agama Islam dalam....

oleh siswa yaitu merokok, berkelahi, pacaran dilingkungan sekolah, ribut saat proses PBM, berpakaian tidak sesuai dengan aturan dan membolos berturut-turut"

Lain lagi yang diungkapkan oleh guru BK yaitu ibuk Hera, S.Pd.(wawancara 31 Agustus 2021) mengungkapkan: "Selama ini yang pernah dilakukan yaitu terlambat datang kesekolah, keluar kelas saat proses PBM tanpa izin, membolos berturut-turut, dan tidak mengerjakan tugas yang diberikan".

Berdasarkan wawancara yang sudah peneliti lakukan maka kenakalan siswa dapat dikelompokkan menjadi beberapa kelompok, yaitu:

1. Kenakalan Ringan, yang sering kali dilakukan oleh siswa SMPN 6 Bukittinggi diantaranya: (1) Datang terlambang ke sekolah, (2) Keluar kelas saat jam PBM, (3) Tidak mengerjakan tugas yang sudah diberikan oleh guru, (4) Tidur di dalam kelas saat proses PBM, (5) Membolos sekolah, (6) Berpakaian tidak sesuai dengan aturan.

2. Kenakalan yang mengganggu ketentraman dan keamanan orang lain, seperti: (1) Kebut-kebutan di jalan, (2) Menerobos rambu-rambu lalu lintas, (3) Berkelahi dengan teman, (4) Ribut saat proses PBM, (5) Merokok.

3. Kenakalan seksual, seperti: (1) Sudah mulai berpacaran, (2) Berteman tidak mengetahui batas.

\section{Faktor-Faktor Penyebab Kenakalan Siswa SMPN 6 Bukittinggi.}

Banyak faktor penyebab kenakalan siswa di usia remaja ini, salah satu penyebab utamanya adalah dari lingkungan keluarga. Dimana keluarga merupakan lingkungan yang paling dekat untuk membesarkan, mendewasakan dan tempat anak mendapatkan pendidikan untuk pertama kali. Sudarsono (2012). Penelitian menghasilkan bahwa faktor penyebab kenakalan siswa SMPN 6 Bukittinggi yaitu faktor dari keluarga. Permasalahan yang banyak dari lingkungan keluarga yaitu anak kurang mendapat perhatian dari orang tua, kurangnya pendidikan agama yang diberika oleh orang tua, ekonomi yang kurang mencukupi, orang tua yang sibuk bekerja dan kurang memantau anak agar berkarakter dan berakhlak baik. Sedangkan keluarga memiliki peran yang penting dalam perkembangan dan pertumbuhan anak.

Pada usia remaja merupakan sifat alamiah seseorang dalam proses pendewasaan dan pencarian jati diri mereka, disinilah pentingnya peran orang tua terhadap perkembangan para siswa. Sebagaimana diungkapkan oleh ibuk Hera, S. Pd (wawancara 31 Agustus 2021) dalam wawancara: "Jika orang tua tidak jeli dalam memerhatikan anaknya akan berakibat fatal di kemudian hari. Kebanyakan siswa yang melakukan kenakalan dikarenakan orang tua mereka yang sibuk dengan pekerjaan. Terkadang orang tua juga berpikir yang perlu dilakukan untuk anak hanyalah mencari uang. Padahal memberikan perhatian kepada anak sangat diperlukan agar sang anak tidak melakukan kenakalan dan dapat diawasi dengan baik".

Kepala Sekolah juga memberikan pendapat yang tidak jauh berbeda, ibuk Syamsimar, S. Pd (wawancara 25 Agustus 2021) mengungkapkan: "Kebanyakan orang tua siswa-siswa kita ini pekerjaannya berjualan, mereka harus pergi pagi sebelum anak mereka sekolah dan pulang berjualan setelah anak mereka tidur. Nah disana siswa ini meresa tidak mendapatkan perhatian, merasa tidak ada yang menyayangi mereka. Karena itulah mereka mencari perhatian dengan melakukan kenakalan-kenakalan".

Faktor kedua dari lingkungan sekolah yang merupakan fasilitator siswa untuk menimba ilmu. Seiring berjalannya waktu sekolah menggunakan teknologi yang sangat canggih untuk menfasilitasi dan penunjang siswa dalam belajar. Tetapi dampak 
negatifnya yaitu penggunaan yang salah oleh siswa yang menimbulkan kenakalan yang tidak semestinya. Selain itu, kedisiplinan sekolah untuk mengatur siswanya merupakan salah satu faktor yang menyebabkan kenakalan siswa terjadi. Karena bagaimanapun siswa akan memiliki rasa takut untuk berbuat nakal dan menjadi disiplin bila sekolah telah membuat peraturan yang sangat ketat.

Berdasarkan hasil observasi dan wawancara peneliti menemukan bahwa salah satu faktor penyebab kenakalan siswa di SMPN 6 Bukittinggi yaitu pergaulan yang salah. Di usia remaja yang sangat rentan dengan salah dalam bergaul yang berujung merugikan diri sendiri dan orang lain. Hasil wawancara dengan guru PAI yaitu Mauli Wardi, S. PdI (wawancara 24 Agustus 2021) mengungkapkan: "Banyak siswa SMP yang bergaul dengan orang yang tidak sebaya atau usianya lebih dewasa misalnya anak SMA, mahasiswa dan bahkan bergaul dengan orang putus sekolah. Karena diusia remaja ini siswa sangat rentan dengan rasa ingin tahu dan mencoba hal-hal baru yang tidak mereka sadari akan berakibat merugikan diri sendiri maupun orang lain. Salah pergaulan ini juga dapat mempengaruhi cara pikir anak remaja SMP yang belum waktunya mereka jangkau atau mereka lakukan yang akhirnya akan merugikan diri mereka sendiri dan orang lain. Di usia remaja ini sangat perlu ditanamkan moralitas agar bisa berpikir sesuai dengan usianya".

Faktor ketiga berasal dari faktor lingkungan, yaitu pergaulan di luar maupun di dalam lingkungan sekolah, siswa SMP masih tergolong labil dalam menentukan dan memutuskan sesuatu dan kurang bisa meyakinka diri akan hal baik dan buruk untuk diri sendiri maupun orang lain. Itu disebabkan oleh rasa ingin tahu akan hal baru dan juga keinginan untuk mencari perhatia orang lain, banyak dari siswa ingin dipandang dewasa karena salah dalam bergaul atau memilih teman.

Bapak Firman Adhani, S. Pd selaku Waka Kesiswaan (wawancara 31 Agustus 2021) juga mengungkapkan hal yang sama yaitu: "Karena sekolah kita strategis, maka di situ juga pergaulan para siswa juga bercampur aduk, ada yang temannya anak yang tidak sekolah, temannya yang lebih dewasa dari mereka. Siswa yang masih SMP masih sulit untuk memilah-milah teman yang baik untuk mereka".

Kemudian Ibu Rahmi Chandra, S. PdI (wawancara 24 Agustus 2021) mengatakan bahwa: "Seringkali siswa-siswa kita ini salah dalam pergaulan, ikut-ikut teman. Mereka tidak bisa memilih teman mana yang baik untuk mereka. Mereka hanya berteman dengan siswa-siswa yang trendi menurut mereka. padahal seharusnya kita berteman dengan orang yang bisa membawa kita ke arah yang lebih baik".

Menurut hasil penelitian yang dilakukan, faktor ini sesuai dengan teori yang disebutkan oleh Sudarsono (2012) yang menjelaskan bahwa ada 3 faktor yang menyebabkan kenakalan siswa yaitu keadaan keluarga, keadaan teman dan lingkungan masyarakat.

\section{Upaya Guru PAI dalam Menanggulangi Kenakalan Siswa SMPN 6 Bukittinggi.}

Setelah dikemukakan tentang berbagai bentuk kenakalan siswa SMPN 6 Bukittinggi dan faktor-faktor penyebabnya, hal tersebut memerlukan upaya untuk mengatasi masalah agar kenakalan yang terjadi pada siswa tersebut dapat teratasi. Apabila kenakalan tersebut tidak diatasi maka akan berakibat buruk terhadap perkembangan 
Ana Maulida dan Rini Rahman: Peran Guru Pendidikan Agama Islam dalam....

siswa SMPN 6 Bukittinggi dan pendidikannya juga akan mengalami kesulitan bahkan kegagalan.

Upaya Guru Pendidikan Agama Islam dalam menanggulangi kenakalan ringan, berdasarkan hasil wawancara dengan Ibu Rahmi Chandra S.Pd.I (wawancara 24 Agustus 2021) selaku guru PAI di SMPN 6 Bukittinggi mengatakan: "Untuk kenakalan ringan upaya yang biasa dilakukan berbentuk teguran, sekali atau dua kali di tegur tapi masih melakukan hal tersebut maka akan dilakukan tindakan. Contohnya siswa-siswa yang tidak berpakaian bersih atau rapi. Satu dua kali akan ditegur terlebih dahulu, namun jika masih tetapi tidak didengar, maka kita akan coret baju mereka. hal tersebut dilakukan bukan tanpa adanya alasan. Jika baju mereka sudah dicoret, maka siswasiswa kita akan merasa malu dan merapikan pakaian mereka".

Hal di atas juga dikuatkan oleh pendapat dari bapak Mauli Wardi, S. Pd.I (wawancara 24 Agustus 2021) yang juga guru PAI di SMPN 6 Bukittinggi, beliau menyampaikan: "Kenakalan ringan ini diatasi dengan menegur siswa-siswa tersebut, selain itu kita juga berupaya untuk mengingatkan para siswa dengan cara menyisihkan sedikit waktu dalam setiap proses pembelajaran di kelas. Dan juga ketika kultum di sekolah pada hari jumat guru PAI ikut serta memberikan ceramah, jika siswa tersebut masih melakukan pelanggaran, makan akan diberikan tindakan tegas oleh pihak sekolah. Dari observasi yang penulis lakukan di SMPN 6 Bukittinggi bahwa sering kali guru-guru yang menegur siswa-siswa nya yang melakukan pelanggaran-pelanggaran kecil. Contohnya ada siswa yang berpakaian tidak rapi maka akan ditegur untuk merapikan pakaian mereka.

Dari pernyataan diatas, maka dapat disimpulkan bahwa kenakalan ringan pada siswa akan diatasi dengan terguran. Para guru memberikan terguran kepada siswa untuk tidak melakukan hal yang dilarang. Namun jika siswa masih tidak mengindahkan teguran tersebut, maka guru akan bertindak untuk membuat siswa tersebut jera.

Upaya Guru Pendidikan Agama Islam dalam menanggulangi kenakalan yang mengganggu ketenteraman dan keamanan orang lain, dari wawancara yang dilakukan dengan Ibu Rahmi Chandra, S.Pd.I (wawancara 24 Agustus 2021) beliau menyatakan: "Untuk kenakalan yang mengganggu ketenteraman dan keamanan orang lain guru PAI juga melakukan upaya yang lebih khusus, yaitu dengan cara melakukan pendekatan khusus dengan terapi keagamaan agar siswa benar-benar memahami dan menyesali bahwa perilaku yang dilakukan tidak termasuk ajaran agama. Mengadakan pendekatan khusus terhadap orangtua siswa yang melakukan kenakalan, dengan harapan orangtua dapat menjadi motivator siswa untuk menghindari perbuatan buruk".

Wawancara peneliti dengan Bapak Mauli Wardi, S.Pd.I (wawancara 24 Agustus 2021) beliau mengungkapkan: "Contoh kenakalan siswa yang mengganggu ketenteraman dan keamanan orang lain yaitu kebut-kebutan dijalan dan melanggar rambu lalu lintas. Upaya yang dilakukan adalah memanggil siswa tersebut dan diberikan nasehat-nasehat pengarahan bagaimana di usia mereka belum dibolehkan berkendara, umur yang masih dibawah 18 tahun dan belum memiliki SIM. Selain itu juga ada sosialisasi yang dilakukan pihak sekolah dengan kopolisian. Dengan mengundang pihak kepolisian dan memberikan pengarahan kepada siswa, hal tersebut menambah pengetahuan siswa tentang tata tertib berkendaran dan mereka akan berfikir kembali untuk melakukan hal tersebut".

Dari pernyataan di atas maka dapat disimpulkan bahwa upaya dari guru PAI untuk menanggulangi kenakalan yang mengganggu ketenteraman dan keamanan orang lain 
yaitu dengan memberikan terapi keagamaan, pendekatan khusus dengan siswa yang bersangkutan dan orang tua, serta pihak sekolah akan mengundang pihak-pihak yang bisa mengarahkan siswa untuk tidak melakukan pelanggaran.

Upaya guru Pendidikan Agama Islam dalam menanggulangi kenakalan seksual, Guru PAI SMPN 6 Bukittinggi yaitu bapak Mauli Wardi, S. Pd (wawancara 24 Agustus 2021) menyatakan bahwa: "Kenakan seksual ini levelnya sudah tinggi dan penanggulangannya melibatkan segala pihak, diantaranya wali kelas, guru BK daan guru PAI, Kepala Sekolah, Wakil Kepala Sekolah, orang tua, bahkan sampai ke Komisi Perlindungan Anak".

Berdasarkan wawancara dengan bapak Firman Adhani, S.Pd (wawancara 25 Agustus 2021) selaku Waka Kesiswaan SMPN 6 Bukittinggi mengenai hal tersebut beliau menuturkan: "Jika ada anak yang melanggar peraturan sekolah, pertama guru kelas yang akan menangani, ketika belum bisa maka permasalahan akan di pindahkan kepada guru Bimbingan Konseling, dan ketika belum juga tuntas maka Waka Kesiswaan akan bertindak langsung, dan terakhir akan di komunikasikan dengan orang tua jika dirasa memang perlu melibatkan orang tua. Jika sampai alternatif terakhir ini tidak juga bisa menyelasaikan, maka siswa, orang tua dan sekolah melakukan perjanjian tertulis dan langkah terakhir adalah diberikannya surat penguduran diri alias pihak Sekolah akan mengembalikan siswa kepada orang tua /wali yang bersangkutan".

Pernyataan yang sama juga disampaikan oleh ibu Rahmi Chandra, S.Pd.I, (wawancara 24 Agustus 2021) beliau mengatakan: "Jika ada anak kita yang melakukan kenakalan seksual, maka kita pihak sekolah akan segera cepat tanggap, siswa tersebut di panggil beserta orang tuanya dan langsung berhadapan bersama Waka Kasiswaan. Jika sudah berurusan dengan Waka Kesiswaan otomatis didampingi oleh Kepala Sekolah. Jika pelanggaran terlalu berat, maka siswa tersebut bisa terkena skors, diberikan waktu untuk berfikir mau tetap bersekolah di sini dengan syarat menandatangani surat perjanjian atau mengundurkan diri dari SMPN 6 Bukittinggi".

Dari pernyataan di atas maka dapat disimpulkan jika kenakalan seksual terjadi maka siswa SMPN 6 Bukittinggi akan melalui proses yang melibatkan semua pihak, Guru PAI tidak bisa hanya sendiri untuk mengatasi kenakalan seksual ini. Guru PAI akan bekerja sama dengan orang tua, guru BK, Waka Kesiswaan, dan Kepala Sekolah.

Upaya guru PAI dalam mengatasi kenakalan siswa SMPN 6 Bukittinggi ada 2 metode yaitu Preventif (Pencegahan) dan Kuratif (Penyembuhan). Hal ini sesuai dengan teori yang disebutkan oleh Jatmiko (2004: 44) upaya untuk mengatasi dan mencegah kenakalan dikelompokkan menjadi tiga yaitu Preventif, Represif dan Kuratif.

Peneliti menemukan upaya yang digunakan oleh guru PAI di SMPN 6 Bukittinggi untuk mengatasi kenakalan siswa yang terjadi di lapangan. Pertama yaitu preventif, dimana guru akan membuat jadwal di hari-hari tertentu untuk membangun dan meningkatkan karakter serta akhlak pada siswa yang tujuannya sebagai pertahanan bagi siswa yang ingin melakukan kenakalan dengan cara pembinaan moral. Selain untuk membiasakan siswa untuk berbuat baik, guru juga harus menjadi teladan bagi 
Ana Maulida dan Rini Rahman: Peran Guru Pendidikan Agama Islam dalam....

siswa-siswanya yang sesuai dengan pendapat Buya Hamka. Karena guru adalah suri tauladan yang dijadikan panutan serta contoh oleh peserta didiknya.

Upaya preventif yang dilakukan oleh SMPN 6 Bukittinggi diantaranya: Melaksanakan kegiatan keagamaan di sekolah, hasil wawancara dengan ibu Rahmi Chandra S.Pd.I, (wawancara 24 Agustus 2021) beliau mengatakan: "Kegiatan kegamaan yang dilaksanakan SMPN 6 Bukittinggi selain untuk menambah wawasan agama juga berfungsi sebagai pencegahan (preventive) terjadinya kenakalan siswa. Kegiatan keagamaan yang dilakukan contohnya adalah kita melaksanakan Peringatan Hari Besar Islam (PBHI), Mengadakan pesantren kilat pada bulan Ramadhan, dan melaksanakan kultum setiap hari Jumat".

Hal yang serupa juga dikatakan oleh bapak Mauli Wardi, S. PdI, (wawancara 24 Agustus 2021) yaitu: "Untuk upaya pencegahan biasanya kita akan menekankan kepada siswa nilai-nilai agama di setiap sebelum proses pembelajaran, melaksanakan Peringatan Hari Besar Islam (PHBI), melakukan kultum setiap hari jumat dan sesekali akan ada di datangkan ustad-ustad untuk memberikan ceramah, melaksanakan muhadharah dan berdoa bersama. Selain itu di SMPN 6 Bukittinggi setiap memulai pembelajaran kita melakukan tadarus Al-Quran".

Wawancara dengan guru BK yaitu ibu Hera, S. Pd (wawancara 31 Agustus 2021) beliau mengemukakan bahwasanya: "Dengan melakukan kegitan keagamaan sangat mempengaruhi kejiwaan siswa, sehingga siswa selalu sadar dan senantiasa untuk berbuat baik dan hal tersebut dapat menenangkan hati siswa, secara tidak langsung akan mengurangi kenakalan siswa".

Kedua, Guru Pendidikan Agama Islam bekerja sama dengan Guru BK, berdasarkan hasil wawancara dengan bapak Mauli Wardi, S. PdI (wawancara 24 Agustus 2021) beliau mengatakan: "Pencegahan kenakalan siswa SMPN 6 Bukittinggi perlu adanya kerjasama antara guru PAI dengan guru BK. Guru PAI dan guru BK melakukan diskusi mengenai masalah-masalah siswa dengan tujuan untuk memperoleh masukanmasukan atau akar dari berbagai masalah kenakalan sisswa di SMPN 6 Bukittinggi".

Pernyataan di atas dikuatkan oleh Kapala Sekolah yaitu ibu Syamsimar, S. Pd (wawancara 25 Agustus 2021) beliau mengatakan: "Guru PAI melakukan diskusi dengan guru BK mengenai masalah-masalah siswa dengan tujuan untuk memperoleh masukan-masukan dalam menangani kenakalan siswa".

Waka Kesiswaan yaitu bapak Firman Adhani, S.Pd (wawancara 31 Agustus 2021) menyatakan hal yang sama, yaitu: "Biasanya guru BK dengan guru PAI ini memiliki jadwal tersendiri untuk berdiskusi mengenai kenakalan-kenakalan siswa ini. Tujuan nya agar guru PAI dan guru BK bisa bertukar pikiran guna untuk pencegahan yang akan dilakukan untuk kenakalan siswa". Maka dapat disimpulkan bahwa guru PAI perlu menjalin hubungan kerjasama dengan guru BK untuk berdiskusi, bertukar pikiran mengenai pencegahan yang akan dilakukan untuk mengurangi kenakalan siswa tersebut.

Ketiga, menekankan pembinaan moral dan agama. Wawancara dengan ibu Rahmi Chandra, S.Pd.I (wawancara 24 Agustus 2021) beliau menyatakan: "Setiap hari harus menanamkan nilai-nilai agama dan moral kepada siswa. Kewajiban dan kesadaran mereka untuk sholat, kesadaran mereka untuk membaca Alquran. Kita beri motivasi, 
kalau sholat kita sudah benar Insya Allah perbuatan, tingkah laku dan bahasa yang kita pakai pasti bagus. Yakinkan kepada mereka bagaimana Allah itu ada”.

Hasil wawacara dengan Ibu Syam (wawancara 25 Agustus 2021) yaitu: "Mengadakan pembinaan dan penyuluhan agama dan moral sangat penting untuk dilaksanakan, agar siswa benar-benar memahami bahwa perilaku yang dilakukan tidak termasuk ajaran agama". Hal yang tidak jauh berbeda dituturkan oleh bapak Wardi, (wawancara 24 Agustus 2021) yaitu: "Pembinaan moral dan agama sangat penting dilakukan kepada siswa, karena jika moral dan agama sudah tertanam dengan baik makan akan mudah menghadapi dorongan/pengaruh dari luar. Hal ini dilakukan dengan penyampaian Kepala Sekolah pada saat upacara hari Senin dan kultum yang dilakukan setiap hari Jumat".

Berdasarkan penjelasan di atas dapat di simpulkan bahwa pembinaan moral sangat penting karena dengan adanya pembinaan moral akan tertanam akhlak dan kepribadian yang baik pada siswa. Sehingga mempu menghadapi pengaruh-pengaruh ari luar yang bersifat negatif. Sedangkan dalam upaya kuratif, guru akan melakukan metode penyembuhan bagi siswa yang sudah terlanjur malaukan kenakalan. Hal yang perlu dipelajari dalam strategi penyembuhan adalah melakukan pendekatan terlebih daluhu kepada siswa dan tidak menekan siswa sehingga mereka merasa terintimidasi.

Pertama, pendekatan langsung dengan siswa yang bermasalah. Upaya pendekatan ini dilakukan untuk memperoleh akar permasalahan yang menyebabkan kenakalan siswa sehingga dapat ditemukan cara untuk mengatasi kenakalan tersebut. Upaya penanganan yang dilakukan oleh bapak Mauli Wardi, S. Pd (wawancara 24 Agustus 2021) selaku guru PAI adalah: "Upaya penyembuhan atau penanganan yang biasa bapak gunakan yaitu menegur dan menasehati siswa yang bermasalah dengan menggunakan pendekatan agama, memberikan perhatian dan pendekatan khusus jika siswa tersebut tidak tampak perubahan tingkah lakunya, apabila dengan tidak berubah setelah diberikan hukuman maka guru PAI akan mengadakan keunjungan rumah bersama guru BK".

Hal yang serupa juga dikatakan oleh Rahmi Chandra, S. PdI (wawancara 24 Agustus 2021) beliau mengatakan: "Selama ini jika ada siswa-siswa yang sudah seringkali melanggar maka akan dilakukan pendekatan terlebih dahulu, dipanggil siswa tersebut dan di tanya baik-baik, dinasehati baik-baik jangan langsung me-judge siswa tersebut sebagai anak nakal. Setelah di nasehati siswa tersebut akan kita pantau, ada perubahan atau tidak karena siswa-siswa kita ini perlu didekatkan dengan rasa".

Hasil wawancara bersama ibu Hera, S. Pd (wawancara 31 Agustus 2021) menegaskan hal diatas, yaitu: "Upaya penyembuhan dilakukan dengan cara memberikan teguran dan nasehat, memberikan pengarahan bagaimana bersikap yang baik, diharapkan dengan cara ini siswa bisa menyadari kesalahan dan berusaha memperbaiki atas apa yang telah dia lakukan. Apabila masih dilakukan maka siswa kita akan diberikan sanksi sesuai dengan tingkat kenakalannya, mulai dari peringatan, memanggil orang tua siswa, membuat surat perjanjian, scorsing atau bahkan dikembalikan kepada orang tua siswa".

Dari hasil wawancara di atas maka dapat disimpulkan bahwa pendekatan sangat dibutuhkan dengan siswa. Melalui pendekatan yang kita lakukan makan akan 
Ana Maulida dan Rini Rahman: Peran Guru Pendidikan Agama Islam dalam....

mempermudah kita untuk mencari akar permasalahan dan penyebab kenakalan siswa sehingga kita dapat mengatasi kenakalan siswa tersebut dengan baik.

Kedua, menjalin kerjasama dengan pihak tertentu dan orang tua siswa. Hasil wawancara dengan bapak Mauli Wardi, S. Pd (wawancara 24 Agustus 2021) selaku guru PAI mengungkapkan: "Bahwasanya untuk mengatasi kenakalan siswa yang ada di SMPN 6 Bukittinggi pihak sekolah harus berusaha untuk menjalin hubungan baik dengan orang tua siswa. Hal tersebut dilakukan dengan cara mengundang orang tua wali murid untuk datang ke sekolah pada waktu pembagian raport sekaligus membicarakan masalah perkembangan siswa dan masalah pendidikan, hal tersebut lebih tegas dalam menerapkan kedisiplinan siswa".

Hasil wawancara dari ibu Syamsimar, S. Pd (wawancara 25 Agustus 2021) beliau mengungkapkan: "Disamping ilmu agama perhatian orang tua juga dangat dibutuhkan. Membicarakan kenakalan siswa dengan orang tua akan membuat orang tua memberikan perhatian lebih kepada anak mereka. Dengan mengetahui kenakalan yang anak mereka lakukan, maka para orang tua akan mendisiplikan anak mereka. karena para orang tua akan merasa tidak nyaman dipanggil kesekolah atas kenakalan anak mereka" Sedangkan hasil wawancara dengan ibu bapak Firman Adhani, S. Pd (wawancara 31 Agustus 2021) mengungkapkan: "Untuk upaya penyembuhan ini harus diikut sertakan orang tua dan guru agama. Hal ini berfungsi untuk menyadarkan siswa yang nakal agar menyadari kesalahan dan mau untuk memperbaiki diri serta menjadi pribadi yang lebih baik".

Dari pernyataan di atas maka dapat disimpulkan bahwa menjalin kerjasama dengan orang tua siswa sangat diperlukan. Karena orang tua dapat memantau anak-anak mereka dengan ketat dan memperbaiki serta menanam kembali akhlak yang baik kepada sang anak.

Ketiga, bekerja sama dengan pihak kepolisian setempat. Berdasarkan hasil wawancara dengan bapak Firman Adhani, S. Pd (wawancara 31 Agustus 2021) selaku Wakil Kesiswaan SMPN 6 Bukittinggi mengatakan bahwa: "Pihak kepolisisan setempat turun langsung dan memberikan pengarahan agar kenakalan siswa benar-benar bisa ditanggulangi dan disembuhkan"

Hal yang sama juga disampaikan oleh Kepala Sekolah yaitu ibu Syamsimar, S. Pd (wawancara 25 Agustus 2021): "Pihak kepolisian memberikan pembinaan dengan cara memberitahu hal-hal yang tidak boleh dilanggar dan memberi tahu akibat jika siswa melanggar hal tersebut. Kepolisian juga akan memanggil orang tua jika kenakalan yang mereka lakukan sudah parah dan juga pihak sekolah yang mewakili. Pembinaan dari pihak kepolisiaan juga bersifat tertutup dan menekal mental siswa agar mereka jera dan mengakui kesalahan serta mau untuk memperbaiki kesalahan tersebut. Pihak kepolisian yang menangani hal tersebut adalah pihak kepolisian yang memahami psikologi remaja di usia SMP".

Wawancara dari ibu Hera, S. Pd (wawancara 31 Agustus 2021) selaku guru BK yaitu: "Tahap penyembuhan juga harus bersangktan dengan pihak kepolisian setempat agar kenalan siswa benar-benar bisa di tanggulangi dan disembuhkan"

Dari pernyataan di atas maka dapat disimpulkan bahwa bekerja dengan pihak kepolisian menjadi salah satu tahap penyembuhan untuk kenakalan siswa. Menekan mental siswa yang dilakukan oleh pihak kepolisian bukan tekanan mental yang 
berakibat buruk, tetapi untuk membuat siswa-siswa tersebut menjadi jera dan menyembuhkan kenakalan.

Upaya kuratif ini cenderung lebih sulit dikarenakan siswa sudah terlanjur melakuakan kenakalan dan yang lebih menyulitkan lagi jika siswa merasa apa yang mereka lakukan itu benar tanpa adanya penyesalan. Berdasarkan hasil penelitian hal yan perlu dilakukan oleh guru PAI adalah melakukan pendekatan tanpa mengintimidasi agar siswa tersebut merasa nyaman dan tidak menghindar. Ketika sudah melakukan pendekatan guru PAI mulai dengan memberikan nasehat dan melakukan pembinaan moral.

Guru PAI berperan penting dalam mengatasi kenakalan siswa dikarenakan guru PAI lebih menekankan kedalam hal spiritual, bukan ke dalam hal sosial yang mengkin akan membuat siswa tersebut tidak peduli dengan nasehat itu. Spiritualitas yang di tanamkan melalui perilaku guru yang menjadi figur utama dalam pengaplikasian akhlakul karimah. Seperti berbicara dengan kata yang baik, sopan santun dalam perbuatan, menghormati dan bersalaman setiap bertemu dengan semua guru. Dan kenakalan siswa yang belum teratasi, juga merupakan kegagalan guru PAI sebagai pembimbing moral siswa di sekolah.

\section{Simpulan}

Bentuk-bentuk kenakalan siswa di SMPN 6 Bukittinggi terbagi menjadi tiga macam. Yaitu kenakalan ringan, kenakalan yang mengganggu ketentraman dan keamanan orang lain dan kenakalan seksual. Faktor yang menyebabkan kenakalan siswa di SMPN 6 Bukittinggi yaitu: Pertama, Lingkungan keluarga, penyebab utama di lingkungan keluarga yang menyebabkan kenakalan adalah: keluarga yang broken home, perceraian orang tua sehingga anak merasa tidak diperhatikan, orang tua yang terlalu sibuk dan ekonomi yang tidak stabil. Kedua, Lingkungan sekolah/pergaulan, selain lingkungan keluarga sekolah dan pergaulan merupakan salah satu faktor penyebab kenakalan karena siswa disekolah banyak bergaul dengan teman-temannya yang bermacammacam karakter.

Upaya guru PAI dalam menanggulangi kenakalan siswa di SMPN 6 Bukittinggi yaitu mengadakan kegiatan keagamaan seperti: Peringatan Hati Besar Islam (PHBI), mengadakan pesantren kilat dan lain-lain. Guru PAI bekerjasama dengan guru BK. Dengan terjalinnya kerjasama dengan guru BK akan mempermudah guru dalam memahami karakter siswa. Menjalin kerjasama dengan pihak tertentu dan orang tua siswa, hal ini dilakukan dengan cara mengundang orang tua wali murid untuk datang ke sekolah pada waktu pembagian raport sekaligus membicarakan masalah perkembangan siswa dan masalah pendidikan, hal tersebut lebih tegas dalam menerapkan kedisiplinan siswa. Bekerja sama denga pihak kepolisian, pihak kepolisian memberikan pembinaan dengan cara memberitahu hal-hal yang tidak boleh dilanggar dan memberi tahu akibat jika siswa melanggar hal tersebut. Pihak kepolisian yang menangani hal tersebut adalah pihak kepolisian yang memahami psikologi remaja di usia SMP. Pendekatan langsung dengan siswa yang bermasalah, upaya pendekatan ini dilakukan untuk memperoleh akar permasalahan yang menyebabkan kenakalan siswa sehingga dapat ditemukan cara untuk mengatasi kenakalan tersebut.

\section{Referensi}


Ana Maulida dan Rini Rahman: Peran Guru Pendidikan Agama Islam dalam....

Choiruddin, Muchamad. 2015. Penyesuaian Diri: sebagai Upaya Mencapai Kesejahteraan Jiwa: Jurnal Hisbah. Vol.12 No.1

Daradjah, Zakiah. (1991). Ilmu Jiwa Agama. Jakarta: CV Mas Agung.

Darmiah. 2017. Strategi Pembelajaran Pendidikan Agama Islam di Sekolah Lanjutan Menengah Atas dan Pengaruhnya terhadap Pembangunan Karakter: Pionir Jurnal Pendidikan. Vol.6 No.1

Fatimah. 2018. Peran Guru Pendidikan Agama Islam dalam Menanggulangi Kenakalan Remaja di SMA N 1 Belo: Skripsi. Fakultas Ilmu Tarbiyah dan Keguruan UIN Maulana Malik Ibrahim Malang

Hisyam, M. W. (2020) . Upaya guru Pendidikan Agama Islam dalam menanggulangi kenakalan siswa di SMPN 2 Watulimo Trenggalek (Doctoral dissertation, Universitas Islam Negeri Maulana Malik Ibrahim).

Jannah, Miftahul. 2016. Remaja dan Tugas-Tugas Perkembangannya dalam Islam: Jurnal Psikoislamedia. Vol.1 No.1

Khusaini. 2015. Peran Guru Pendidikan Agama Islam dalam Menanggulangi Kenakalan Siswa di SMKN 4 Malang: Skripsi. Fakultas Ilmu Tarbiyah dan Keguruan UIN Maulana Malik Ibrahim Malang.

Lickona, Thomas. (2002). Persoalan Karakter. Jakarta: PT. Bumi Aksara

Mandasari, Devia. 2018. Persepsi Masyarakat terhadap Akhlak Remaja di Desa Candimas Kecamatan Abung Selatan Kabupaten Lampung Utara: Skripsi. Universitas Islam Negeri Raden Intan Lampung

Prasanti, Ditha. 2018. Penggunaan Media Komunikasi bagi Remaja Perempuan dalam Pencarian Informasi Kesehatan: Jurnal Lontar. Vol.6 No.1

Prasasti, S. (2017). Kenakalan remaja dan faktor penyebabnya. In Prosiding Seminar Nasional Bimbingan dan Konseling (Vol. 1, No. 1, pp. 28-45).

Pratiwi, Nuning Indah. 2017. Penggunaan Media Video Call dalam Teknologi Komunikasi: Jurnal Ilmiah Dinamika Sosial. Vol.1 No.2

Rogi, B. A. (2015). Peranan komunikasi keluarga dalam menanggulangi kenakalan remaja di Kelurahan Tataaran 1 Kecamatan Tondano Selatan. Jurnal Acta Diurna Komunikasi. Vol.4 No.4

Sarwono, W.S. (2002). Psikologi Remaja. Jakarta: Raja Grafindo Persada.

Setiawan, E. (2017). Konsep Pendidikan Akhlak Anak Perspektif Al-Ghazali. Jurnal Kependidikan, Volume 5 Nomor 1.

Sidik, Firman. 2016. Guru Berkualitas Untuk Sumber Daya Manusia Berkualitas: Tadbir: Jurnal Manajemen Pendidikan Islam. Vol.4 No.2

Sinaga, L. V., Kaban, J. R., \& Supratman, E. (2020). Tinjauan Kriminologi Terhadap Kenakalan Remaja (Juvenile Deliquency) Dan Pencegahannya Ditinjau Dari Uu Perlindungan Anak.

Sumara, dkk.. Kenakalan Remaja dan Penanganannya: Jurnal Penelitian dan PPM. Vol.4 No.2 
Unayah, N., \& Sabarisman, M. (2015). Fenomena Kenakalan Remaja dan Kriminalitas.Jurnal Sosio Informa, Vol.1No.2

Yetti, dkk.. 2016. Keanekaragaman Serangga pada Perdu di Kawasan Rinon Pulo Breuh Kabupaten Aceh Besar: Prosiding Seminar Nasional Biotik ISBN: 978-602-189629-7

Yuanita, R. (2019). Pembinaan Akhlak Siswa Di MTS Darul Falah Bendiljati Kulon Sumbergempol Tulungagung. 